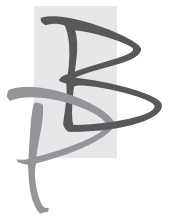

Tetiana Szewczenko*

Odeski Narodowy Uniwersytet im. Ilji Miecznikowa, Ukraina

\title{
Międzynarodowa Konferencja Naukowa „Mit Odessy w kulturze światowej. Teksty - media - wyobrażenia", Białystok, 24-25 IX 2019 roku. Sprawozdanie
}

Zainicjowany w 2013 roku polsko-ukraiński, odesko-białostocki projekt badawczy „Odessa i Morze Czarne. Polsko-ukraińskie związki kulturowe” może się już pochwalić małym jubileuszem. W Białymstoku w dniach 24-25 września 2019 roku obradowała V Międzynarodowa Konferencja Naukowa z tego cyklu, zatytułowana „Mit Odessy w kulturze światowej. Teksty - mediawyobrażenia". Przypomnijmy wcześniejsze spotkania naukowców z Polski i Ukrainy:

- I Międzynarodowa Konferencja Naukowa „Obraz Odessy w literaturach słowiańskich”, Odessa, 12-13 IX 2013 roku.

- II Międzynarodowa Konferencja Naukowa „Odessa i Morze Czarne jako przestrzeń literacka i kulturowa. Idee - konteksty - interpretacje”, Odessa, 15-16 IX 2016 roku.

- III Międzynarodowa Konferencja Naukowa „Muzyka i opera w polskoukraińskim dialogu literackim i kulturowym”, Białystok, 4-5 V 2017 roku.

- IV Międzynarodowa Konferencja Naukowa „Polacy w Odessie i na ukraińskim wybrzeżu Morza Czarnego. Historia - dziedzictwo - współ-

Tetiana Szewczenko - dr, docent na Odeskim Narodowym Uniwersytecie im. Ilji Miecznikowa (Ukraina). 


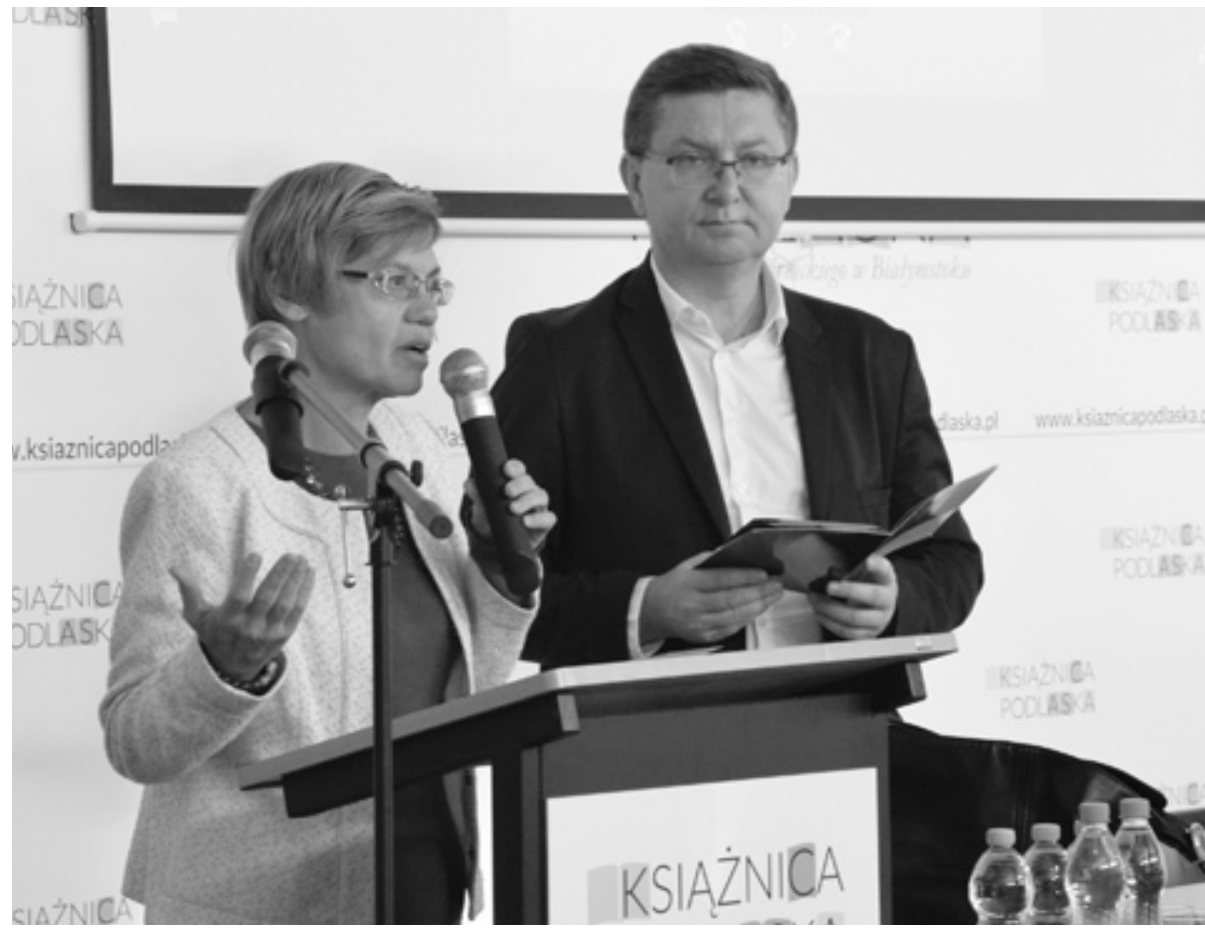

Otwarcie Konferencji. Od lewej: prof. Natalia Maliutina (UwB, Białystok), prof. Jarosław Ławski (UwB, Białystok)

Fot. Bogumiła Maleszewska-Oksztol (Książnica Podlaska)

istnienie wielokulturowej wspólnoty miasta”, Odessa, 10-11 IX 2018 roku $^{1}$.

Na prawach wzajemności i gościnności V Konferencja odbyła się w Białymstoku. Zorganizowały ją wspólnie Wydział Filologiczny Uniwersytetu w Białymstoku, Katedra Badań Filologicznych „Wschód - Zachód” UwB, Wydział Filologiczny Odeskiego Narodowego Uniwersytetu im. Ilji Miecznikowa, Muzeum Literatury w Odessie i Książnica Podlaska im. Łukasza Górnickiego. Tegoroczna sesja została przygotowana jako część projektu fi-

1 Z tego cyklu wydano dotychczas monografie: Odessa w literatura słowiańskich. Studia, red. J. Ławski, N. Maliutina, Białystok - Odessa 2016; Odessa i Morza Czarne jako przestrzeń literacka, red. J. Ławski, N. Maliutina, Białystok - Odessa 2019; Odessa, muzyka, literatura. Ukraińsko-polski transfer kulturowy i literacki. Studia, red. N. Maliutina, W. Biegluk-Leś, wstęp i układ J. Ławski, Białystok 2019. 


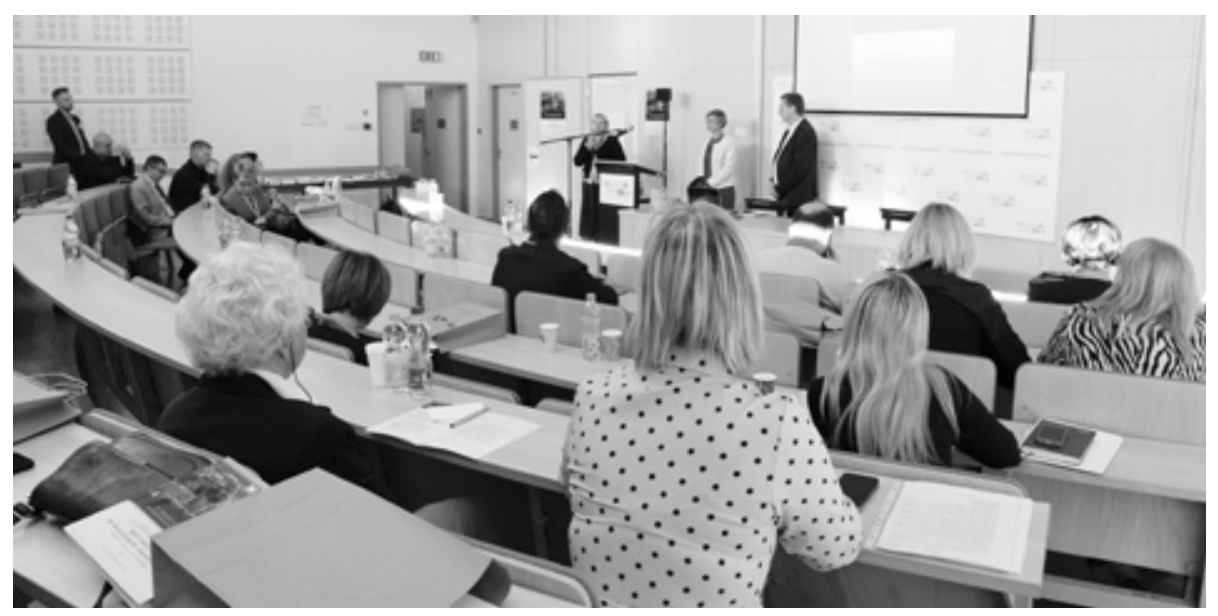

Otwarcie Konferencji, pierwszy dzień obrad

Fot. Bogumiła Maleszewska-Oksztol (Książnica Podlaska)

nansowanego w ramach programu Ministerstwa Nauki i Szkolnictwa Wyższego pod nazwą $>$ Regionalna Inicjatywa Doskonałości< na lata 2019-2022, nr projektu 009/RID/2018/19, kwota finansowania 8791 222,00 zł. Dzięki wsparciu z projektu RID mogła odwiedzić Białystok spora grupa badaczy odeskich, którzy byli tym razem głównymi prelegentami. Sesję przygotowywali, tak jak od lat, dr hab. Natalia Maliutina, prof. UwB (Odessa i Białystok) i prof. Jarosław Ławski (UwB), wspólnie przewodniczący Komitetowi Organizacyjnemu². W jego skład weszło liczne grono badaczy z Działu Naukowego Książnicy Podlaskiej, a także Dyrektor tejże placówki, Pani Jolanta Gadek. W 2019 roku podjęto następujące zagadnienia badawcze:

- Literackie wyobrażenia Odessy.

- Odessa jako miasto-mit w historiografii, malarstwie, filmie, sztukach audiowizualnych, teatrze i innych mediach.

2 W skład Komitetu Organizacyjnego weszli nadto: dr Łukasz Zabielski - Książnica Podlaska im. Łukasza Górnickiego, doc. dr Oksana Szupta-Wiazowska - Katedra Literatury Ukraińskiej (Odessa), dr Iryna Neczytaliuk - Katedra Literatury Ukraińskiej (Odessa), dr hab. Anna Janicka, prof. UwB - Wydział Filologiczny (Białystok), dr Robert Szymula - Wydział Filologiczny Uniwersytetu w Białymstoku, dr Kamil K. Pilichiewicz - Wydział Filologiczny Uniwersytetu w Białymstoku, dr Marcin Bajko - Katedra Badań Filologicznych „Wschód Zachód” UwB, dr Michał Siedlecki - Książnica Podlaska im. Łukasza Górnickiego. 
- Ukraińskie i polskie wyobrażenia Odessy wobec wyobrażeń zachodnioeuropejskich i światowych.

- Odessa i Morze Czarne jako przestrzenie wielokulturowe.

Goście z Odessy przybyli do Białegostoku już w niedzielę 22 IX. W poniedziałek (23 IX) wzięli udział w specjalnie przygotowanej wycieczce pokazującej wielokulturowość Podlasia. Plan objazdu przygotowała mgr Izabela Szymańska (Książnica Podlaska), a objął on m. in. wizytę w Supraślu i Kruszynianach. Odesyci byli zaskoczeni trwałą obecnością prawosławia i islamu w polskim krajobrazie kulturowym.

Obrady zainaugurowano we wtorek (24 IX) w Sali Audytoryjnej Książnicy Podlaskiej. Gości powitali prof. Natalia Maliutina (UwB, Odessa) i dyr. Jolanta Gadek, zaś przemówienia wygłosili prof. Walentyna Musij, Zastępca Dziekana Wydziału Filologicznego Uniwersytetu Odeskiego, i prof. Jarosław Ławski (UwB). W czasie inauguracji zaprezentowano odeskie thumaczenie Wspomnień Odessy, Jedyssanu i Budżaku (Wilno 1845) Józefa Ignacego Kraszewskiego dokonane przez panią Alenę Javorską z odeskiego Muzeum Literatury, wydane w 2019 roku; goście z Odessy przekazali Książnicy Podlaskiej i Bibliotece Uniwersyteckiej bogaty zbiór książek naukowych opublikowanych w tym mieście. Obrady plenarne poprzedziła prezentacja osiągnięć slawistyki działającej na Królewskim Uniwersytecie Jordańskim w Ammanie. Wykładowcą ję-

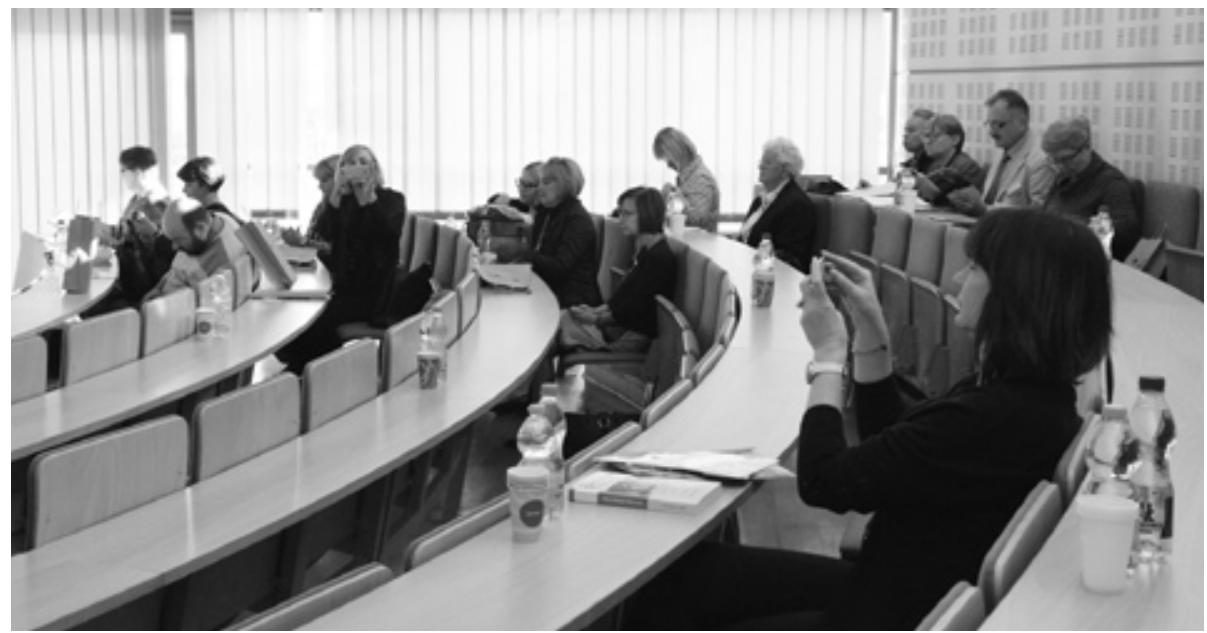

Otwarcie Konferencji, pierwszy dzień obrad

Fot. Bogumiła Maleszewska-Oksztol (Książnica Podlaska) 
zyka rosyjskiego jest tam doktorantka prof. Natalii Maliutiny od lat pracująca w Jordanii - dr Inna Zarovna, współpracująca z Uniwersytetem w Białymstoku i Działem Naukowym Książnicy Podlaskiej. Konferencja, co trzeba dodać, odbywała się pod patronatem Dziekana Wydziału Filologicznego Uniwersytetu Odeskiego prof. Evgena Chernoivanenko.

Pierwszą część obrad poprowadzili prof. Natalia Kondratenko i prof. Jarosław Ławski. Wysłuchano m. in. następujących wystąpień:

- dr hab. Grzegorz Zając (Uniwersytet Jagielloński, Kraków), Dwie Odessy, czyli Kraszewski i Niemcewicz. (Obserwacje powieściopisarza a relacja historyka w podróży);

- prof. Walentina Musij (Odeski Uniwersytet im. I. Miecznikowa), Tonoc «Одесса» в романе Сергея Ануфриева и Павла Пепперитейна «Мифогенная любовь Каст»;

- dr hab. Ewa Szczepkowska (Uniwersytet Warmińsko-Mazurski w Olsztynie), Felicja Jachimowicz - lekarz, balneolog, badacz odeskich literatów;

W części 2. (od godz. 15.00, po przerwie obiadowej) obrad, którą poprowadzili prof. Anna Janicka (UwB) i prof. Jarosław Poliszczuk (UAM, Poznań), wysłuchaliśmy pośród innych referatów następujących prelekcji:

- dr Inna Zarovna (Uniwersytet w Ammanie, Jordania), Культурный опыт античности в наследии одесского театроведа Бориса Варнеке;

- doc. dr Iryna Nechytaluk (Odeski Uniwersytet im. I. Miecznikowa), Пространство одесского дворика в повести Анны Костенко «Цурки-гілки. Джазові імпровізації»;

- doc. dr Tamara Morewa (Odeski Uniwersytet im. I. Miecznikowa), Eda Как слагаемое Одесского мифа в записках Александра Дерибаса;

- doc. dr Tetiana Szewczenko (Odeski Uniwersytet im. I. Miecznikowa), Топология Одессы в эссеистике Б. Херсонского;

- pani Ekaterina Khomenko (Muzeum Literatury w Odessie), Лumepamypный миф Одессы в малоизвестных текстах XIX века.

W czasie obrad zaprezentowano najnowszą ukraińską monografię literackiej Odessy autorstwa prof. Jarosława Poliszczuka (UAM, Poznań) pt. Frontirna identičnost. Odessa XX stolitta (Wydawnictwo „Duch i Litera”, 2019).

W Konferencji wzięło udział 22 badaczy z Białegostoku, Odessy, Poznania, Wrocławia, Olsztyna, Krakowa, Ammanu. Oczywiście grupą dominującą byli badacze ukraińscy: prof. Tetiana Meyzarska (Kijów), doc. dr Oksana 
Szupta-Wiazowska, prof. Walentina Musij, prof. Nadieżda Spodarec, prof. Evgen Chernoivanenko, prof. Olga Jakowlewa, doc. dr Artur Malinowski, doc. dr Tamara Moreva, doc. dr Tatiana Szewczenko (wszyscy z Uniwersytetu Odeskiego), pani Ekaterina Khomento (Muzeum Literatury w Odessie), prof. Evegen Vasilev (Równe). Godzien zauważenia jest udział w sesji prof. Iriny Prochorowej z Moskwy, której przodkowie pochodzili z Białegostoku. Obrady wtorkowe zakończyła uroczysta kolacja. 25 września (środa) goście Konferencji kontynuowali indywidualne spotkania z polskimi partnerami, zwiedzali Białystok i Książnicę Podlaską, a wieczorem udali się do Gdańska na kolejną konferencję3.

Sesję uznano za przedsięwzięcie pożyteczne, udane. Jej plonem będzie kolejna monografia zbiorowa. Prof. Jarosław Poliszczuk (UAM), odpowiadając na apel organizatorów, zaproponował, by VI Konferencja w Odessie poświęcona była kobiecie w przestrzeni literackiej i kulturowej tego miasta.

3 Badacze odescy wzięli jeszcze udział w sesji: „Czas wolny i rozrywka w najnowszej literaturze rosyjskiej”, Gdańsk 26 IX 2019 roku. 